\title{
DENDROCLIMATOLOGICAL RECONSTRUCTION OF SPRING-SUMMER PRECIPITATION FOR FAZENDA RIO GRANDE, PR, WITH SAMPLES OF Araucaria angustifolia (Bertol.) Kuntze ${ }^{1}$
}

\author{
Caren Lorensi $i^{2 *}$ and Alan Prestes ${ }^{3}$
}

\footnotetext{
${ }^{1}$ Received on 19.12.2014 accepted for publication on 16.12.2015.

${ }^{2}$ Universidade do Vale do Paraíba, Programa de Pós-Graduação em Física e Astronomia, São José dos Campos, São Paulo - Brasil. E-mail: <caren.lorensi@gmail.com>.

${ }^{3}$ Universidade do Vale do Paraíba, Instituto de Pesquisa e Desenvolvimento, São José dos Campos, São Paulo - Brasil. E-mail:<aprestes@gmail.com>.

${ }^{*}$ Corresponding author.
}

\begin{abstract}
Samples of Araucaria angustifolia were collected at Fazenda Rio Grande, Paraná, Brazil (2539'S $4918^{\prime} \mathrm{O}$ ) in January 2011. The 32 samples from 8 trees were subjected to treatments following dendrochronological techniques. The cores were measured and dated using optical and computational methodology, and then standardized to obtain a growth-ring time series, which considers the 1907-2009 time range and represents Fazenda Rio Grande. Tree-ring indices were analyzed and correlated to temperature and precipitation averages from the 1961-2009 range. This procedure aimed to study and understand the influence of the local climate on the plant growth and if this influence can be quantified. A. angustifolia trees produce visible annual growth rings, and their earlywood and latewood are clearly defined. The present study shows that $A$. angustifolia is sensitive to climate variables (e.g., low temperatures in wintertime tend to stop the growth rate). The correlation between tree rings and monthly precipitation series showed a common trend, making it possible to estimate the seasonal rainfall behavior for the entire 1907-2009 range.
\end{abstract}

Key-words: Tree-Ring Growth; Dendroclimatology; Time Series.

\section{RECONSTRUÇÃO DENDROCLIMÁTICA DA PRECIPITAÇÃO DA PRIMAVERA- VERÃO PARA FAZENDA RIO GRANDE, PR, COM AMOSTRAS DE Araucaria angustifolia (Bertol.) Kuntze}

\begin{abstract}
RESUMO - Amostras do lenho de Araucaria angustifolia foram coletadas em Fazenda Rio Grande/PR (25'39'S $\left.49^{\circ} 18^{\circ} \mathrm{O}\right)$ em janeiro de 2011. As 32 amostras provenientes de 8 árvores foram submetidas a tratamentos seguindo as técnicas de dendrocronologia. Os núcleos foram medidos e contados usando-se metodologia óptica e computacional, sendo então padronizados para se obter a série temporal de anéis de crescimento do período 1907-2009, que representa o local de estudo. Índices de anéis de crescimento foram analisados e correlacionados com variáveis climatológicas (temperatura e precipitação, ambas de 1961-2009). Este procedimento teve o objetivo de estudar e compreender a influência do clima local no crescimento das plantas e se esta influência pode ser quantificada. As árvores de A. angustifolia possuem anéis de crescimento visíveis com lenho inicial e lenho tardio bem definidos. As análises deste estudo mostram que A. angustifolia é sensivel ao clima e que as baixas temperaturas no inverno interrompem sua taxa de crescimento. A correlação dos anéis de crescimento com a série mensal de precipitação mostrou tendência de crescimento comum entre elas, o que tornou possível estimar o comportamento sazonal da precipitação durante o período 1907-2009 por meio da reconstrução.
\end{abstract}

Palavras-Chave: Anéis de Crescimento de Arvores; Dendroclimatologia; Séries Temporais. 


\section{INTRODUCTION}

In the past, records were found of tree-ring observations of in $370 \mathrm{BC}$, when Theophrasus described tree rings and the relationship between them and the environment (COELHO, 2011). In another paper, Theophrasus relates the climate influence over treering growth and that most trees develop one ring growth annually (SCHWEINGRUBER, 1996). Many years later, extensive research used the tree growth to develop dendroclimatology and its innumerable current applications.

The interaction of trees with environment makes them a rich natural record source. Trees are able to absorb, transform, and accumulate pollutants from the atmosphere (MOREIRA, 2010), which are sometimes retained in the xylem of plants. Lisi et al. (2001), studied xylem from A. angustifolia and Pakia sp before and after nuclear tests in the Northern Hemisphere that began in 1952, and they reported accumulation of ${ }^{14} \mathrm{C}$ in tree rings between 1965-1966.

Natural records are used when instrumental records are inadequate to observe and study climate from greater that a few decades ago (SILVA; PRESTES, 2010). The development of trees can vary between species, and according to age, seasons, and climate (HIGUSHI et al., 2003). Therefore, variation of temperature and precipitation can naturally be registered in tree-ring growth (RIGOZO et al., 2008).

Araucaria angustifolia (Bertol.) O. Kuntze (pinheiro do Paraná) is a conifer that grows mostly southern and southeastern Brazil, northeastern Argentina, and southeastern Paraguay (OLIVEIRA, 2007). This tree has very clear rings with quite distinct early and late wood (SANTAROSA et al., 2007).

Many studies that seek to relate the growth of trees with the climate have used $A$. angustifolia. Oliveira et al. (2010) and Zanon and Finger (2010) investigated climate signals in growth rings of trees collected in Serra Gaúcha (Southern of Brazil). Santarosa et al. (2007), with samples from the same location, determined the existence of a seasonal pattern of tree growth. Dendroclimatology studies with other species, such as Cedrela fissilis, were conducted by Cusatis et al. (2013) to link climate and growth of the samples collected at various sites in the states of Santa Catarina and Paraná.
Some researchers also have used the natural development cycle of the wood and performed seasonal studies, such as Flower and Smith (2010), who studied the influence of temperature of the June-July months on the development of plants collected in the mountains of Canada.

The dendrochronology extends beyond the effect of local climate on plant growth. Some researchers have tried to find periodic signs of El Niño Southern Oscillation (ENSO) events (ENQUIST; LEFFLER, 2001; LORENSI, 2012), monsoon (BORGAONKAR et al., 2010), etc. Paleoclimatology has tried to understand past climate patterns using natural records for the reconstruction of these periods (STOFFEL; PERRET, 2006). Researchers, who study the solar cycle by Sun-Earth relationship, (MURPHY, 1990; PRESTES et al., 2011), use these natural records to explore the climate in the past when there were no instrumental records available.

The aim of this study is to analyze the influence of precipitation and temperature in Araucaria angustifolia samples collected from Paraná (Southern Brazil), to reconstruct a pattern of precipitation for the region.

The state of Paraná is located in a climate transition region with tropical and subtropical north to south (CARVALHO; STIPP, 2004). The samples were collected in Fazenda Rio Grande (25\% $41^{\prime}$ 'S $49^{\circ} 21^{\prime} \mathrm{W}$ ) near Curitiba. According to Carvalho and Stipp (2004), recorded average temperature in Curitiba, during the climatological period 1961-1990, of $16.5^{\circ} \mathrm{C}$, and the months of June and July have the lowest temperatures and the average annual precipitation was around $117.3 \mathrm{~mm}$. Also according to Carvalho and Stipp (2004), Curitiba has the largest amount of precipitation in the summer months and less in March / July / August. Nevertheless, the location does not have a water deficit.

\section{MATERIAL AND METHODS}

\subsection{Climatology Time Series:}

For the development of analysis time series of precipitation and average monthly temperature for Curitiba were used, which were extracted from historical database INMET (Figure 1).

Due to difficulty in obtaining time series of precipitation and temperature for Fazenda Rio Grande, PR, the methodology of Zanzi et al. (2007) was followed 


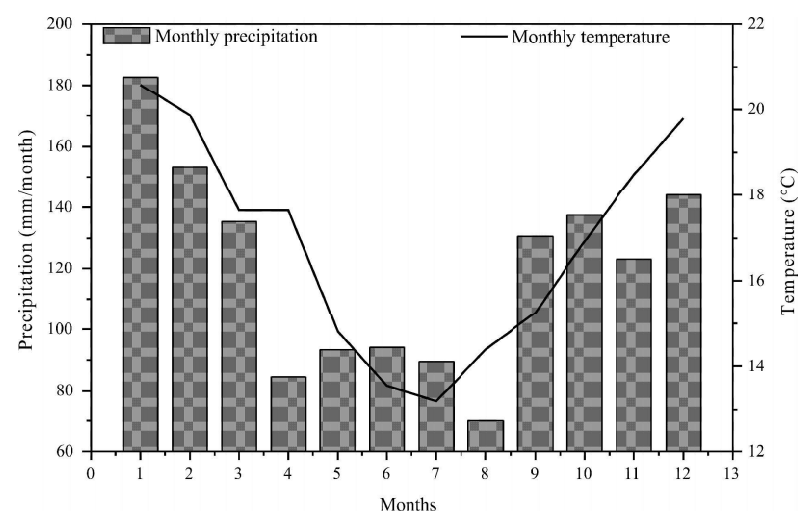

Figure 1 - Time series of average monthly precipitation (gray bars) and average monthly temperature (black line).

Figura 1 - Séries temporais de precipitação média mensal (barras em cinza) e temperatura média mensal (curva em preto) para Curitiba.

in which the authors provide guidance about use of time series from nearby locations surrounding the collection site of the tree samples. Therefore, the average monthly precipitation and temperature from Curitiba was used. From these series, average annual precipitation was calculated.

\subsection{Collection, sample preparation, and construction of local chronology}

In January 2011, 40 samples were collected from 10 individuals by nondestructive method at about 1.2 $\mathrm{m}$ from ground level using the Pressler probe $(5 \mathrm{~mm})$. The collection site is flat and red soil, close to an industrial area. Some trees showed signs of fire and incidence of atmospheric electrical discharges; others were in the middle of a forest.

The samples were accommodated in a wood holder with growth rings longitudinally. This support helps avoid wood deformation to preserve the wood while it naturally dries. After drying, the samples were sanded to remove imperfections and polished to make their growth rings visible. For this, sandpapers of different grit sizes (80-500) were used.

After samples were sanded and polished so that the tree growth rings were visible, the growth rings were marked, which is the first step for counting. Reliable measurements are obtained when the limits of growth rings are first identified and demarcated, to indicate if samples needed more polishing.
Measurements were made on Velmex measurement table with a calibrated displacement accuracy of 0.001 $\mathrm{mm}$, electronically coupled to a microcomputer and associated with a stereoscopic microscope with a micrometer reticle. The dating of annual tree-ring growth was done from the bark to the core starting in 2009 in which referenced the last complete ring formation.

During treatment, measurement, and dating of tree rings, some samples were discarded either because they had very deformed rings, resin marks, or the sample was damaged. Removal of samples with unreliable measures avoids assigning errors to local chronology.

After all the samples were measured and related to the calendar year, the process began to obtain time series for each individual. A correlation was applied between the samples taken from each individual and showed the best coefficient to calculate the average (ENQUIST; LEFFLER, 2001) for obtaining a time series for each individual. The correlation between samples facilitated selection of the best samples, because those with low correlation or with very disparate growth trend in relation to the group were discarded, as suggested by Flower and Smith (2010).

A tree-ring growth series can be composed of a set of environmental factors, so the ring growth may be due to the combination of several elements such as environmental, biological, forest disturbances, etc. (RIGOZO, 1999). Therefore, for the undesirable trends to be eliminated, mathematical functions that represent its individual growth trend were applied from every sample tree series. The objective of this procedure is to obtain the best curve that represents long term trends associated with the growth rate of each series (FICHTLER et al., 2004). This process is called standardization and is supposed to eliminate non-climatic signals present in the dendrochronological series (TROVATI; FERRAZ, 1984).

Standardization is performed by dividing the number of growth rings $\left(R_{t}\right)$ by setting function $\left(G_{t}\right)$, according to Equation 1.

$$
I=\frac{R_{t}}{G_{l}}
$$

The result of this division is the index $(I)$

The adjustment functions used in standardization were linear, polynomial first, second, and third order,

Revista Árvore, Viçosa-MG, v.40, n.2, p.347-354, 2016 
selected among those that showed better correlation with dendrochronological series, as suggested by Savva et al. (2002). Thus, it was possible to observe the growth characteristics of each sample, as well as the persistence of climatic signals.

With the indices, a correlation between individuals and an average was made to obtain the local chronology. According Trovati and Ferraz (1984), the average among the trees offers better relationship with the climate, because the climate signal that influenced the growth of every individual remains when the average is made.

After all treatments were applied, the local chronology was obtained covering the range 19072009 from 32 samples of 8 individuals with a quantity of 1726 analyzed tree rings.

\subsection{Relationship with climatic variables:}

To analyze the influence of climatic variables on tree-ring growth, Pearson correlation was applied to series of annual average precipitation and series of monthly precipitation and temperature for year $\mathrm{T}$ (current year) and year T-1 (previous year). This procedure aims to discover patterns or trends in the annual plant growth that may occur at certain times of year. Correlations were considered significant coefficients that reached $95 \%$ confidence $(p<0.05)$.

Based in the correlation results, it was possible to reconstruct, by linear regression, the profile of the precipitation for months of best growth for the entire range from 1907-2009.

\subsection{Reconstruction of precipitation from September to March}

By linear regression (Equation 2), the profile of precipitation was reconstructed for the months from September to March, which may be registered in the growth rings.

$$
y=\alpha+\beta x
$$

Parameters $\alpha$ (linear coefficient) and $\beta$ (angular coefficient) are estimated by line formed by the linear relationship between series of precipitation from September to March and the index of tree-ring growth series.

Revista Árvore, Viçosa-MG, v.40, n.2, p.347-354, 2016

\section{RESULTS}

\subsection{Relationship between the index of tree rings and climatic variables for year $(T)$ and year $(T-1)$}

The growing season of trees in the Southern Hemisphere begins in the spring of years $T$ until the fall of year T + 1 (CUSATIS et al., 2013); therefore, analyzes were made by adjusting the climatological series for the schedule of the plant.

The correlation between index of the tree-ring growth and annual average precipitation (year T) was significant; the value was $(r=0.2831, p<0.05)$. Thus, an attempt was made to establish the relationship between the chronology of tree- ring growth and precipitation month by month for the year T (Figure 2). Positive and significant correlations occurred in January $(r=0.406, p<0.05)$, February $(r=0.347, \mathrm{p}<0.05)$, and October $(r=0.2816, p<0.05)$, which are the rainiest months. Negative and significant correlation occurred in May $(r=-0.2954, p<0.05)$.

The correlations between the tree-ring growth index and the temperature for $\mathrm{T}$ year were separated by seasons, so the seasonal characteristics would not be "masked". Correlation values are shown in Table 1, where the correlations were significant and negative for the winter.

For the correlation between the tree-ring growth and monthly temperature, August recorded significant anticorrelation $(r=-0.4272, p<0.05)$, followed by July and May, which although strong, were not significant (Figure 2).

The analysis for the previous year $(\mathrm{T}-1)$ between the mean annual precipitation and growth ring index did not obtain a significant correlation. In the month

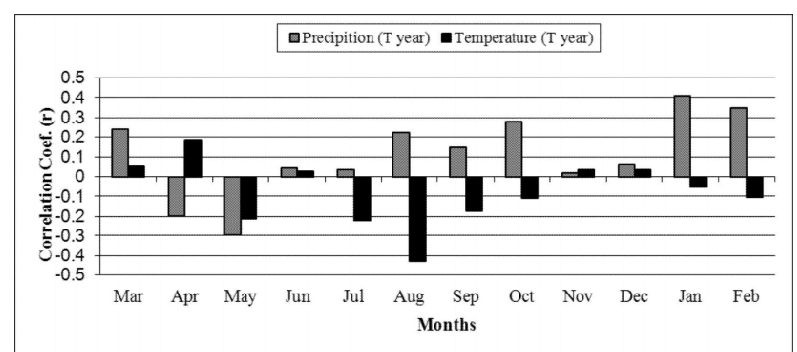

Figure 2-Pearson's correlation coefficient between tree-ring growth index and average monthly precipitation and average monthly temperature for the current year $(\mathrm{T})$.

Figura 2-Coeficiente de correlação de Pearson entre o índice de anéis de crescimento de árvores e a precipitação média mensal e temperatura média mensal para ano corrente (T). 
Table 1 - Correlation between Mean Seasonal Temperature for years T and T-1 and tree-ring growth index. Significant values $(\mathrm{p}<0.05)$ are shown in bold.

Tabela 1 - Correlação entre a Temperatura Média Sazonal para os anos Te T-1 e o índice de anéis de crescimento de árvores. Valores significativos $(p<0.05)$ estão em negrito.

\begin{tabular}{|c|c|c|c|c|}
\hline Average Temperature (T) & Summer & Fall & Winter & Spring \\
\hline Correlation Coefficient (r) & 0.04416 & 0.01707 & -0.30057 & -0.1093 \\
\hline$P$ & 0.07656 & 0.9083 & 0.0381 & 0.4594 \\
\hline \multicolumn{5}{|l|}{ Average Temperature (T-1) } \\
\hline Correlation Coefficient (r) & -0.06205 & -0.050 & -0.4246 & -0.1441 \\
\hline$p$ & 0.6786 & 0.7361 & 0.03 & 0.3345 \\
\hline
\end{tabular}

by month test, some months showed positive correlations and other negative correlations but were not significant (Figure 3).

The values of the correlation coefficients of seasonal temperature in T-1 are shown in Table 1, where winter presented a significant and negative correlation. In assessing month by month, only anticorrelations were significant (August and July), (Figure 3).

\subsection{Relationship of the indices of between tree-ring growth and precipitation for the growth months}

Correlation month by month between precipitation and the tree rings ( $\mathrm{T}$ year) did not show a definite influence profile. The greatest influence may be the set of months during the growing seasons (spring - summer). Therefore, considering all the plant growing season (September to March), precipitation average was calculated for those months and correlated with the index of the growth rings. The correlation coefficient was significant $(r=0.45324, p<0.05)$.

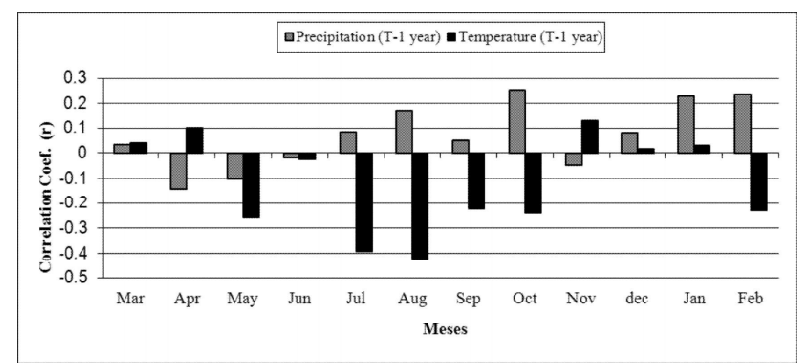

Figure 3 - Pearson's correlation coefficient between treering growth index and average monthly precipitation and average monthly temperature for the previous year ( $\mathrm{T}-1)$.

Figura 3 - Coeficiente de correlação de Pearson entre o indice de anéis decrescimento de árvores e a precipitação média mensal e temperatura média mensal para ano anterior (T-1).
Linear regression (Equation 2) was used to calculate parameters $\alpha$ and $\beta$ and to reconstruct the precipitation profile from September to March.

$$
Y=(0.08444)+(0.55896) I
$$

Where $I$ is the index of tree ring growth.

Later, the reconstruction of precipitation was extended throughout the period of the dendrochronological series (1907-2009) (Figure 4).

Analysis of original precipitation series showed that the rainier periods were 1961-1977 and 1992-2000 (with $212.68 \mathrm{~mm}$ and $223.08 \mathrm{~mm}$, respectively) and less

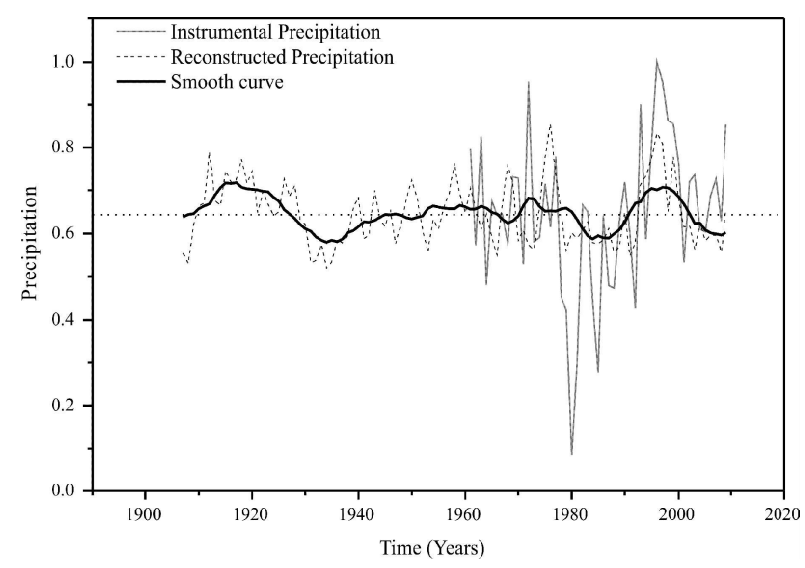

Figure 4-Comparison of original series of precipitation (gray line) and the reconstructed series (dashed black line), average precipitation for SeptemberMarch months for 1907-2009 (horizontal dashed line) and 10-year moving average (black line).

Figure 4-Comparação da série original de precipitação (curva em cinza) e a série reconstruída (curva pontilhada em preto), médiada precipitação paraos meses desetembro a março de 1907-2009 (inha horizontal tracejada) e a média móvel para 10 anos (linha em preto).

Revista Árvore, Viçosa-MG, v.40, n.2, p.347-354, 2016

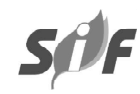


rain occurred in 1978-1992 and 2000-2009 (160.6 mm and $190.3 \mathrm{~mm}$, respectively). These profiles of the drier periods and rainier periods were well represented in the reconstructed series.

\section{DISCUSSION}

The correlations between the tree-ring growth and temperature, illustrated a tendency for negative correlations from July to October, which may indicate that the cold causes dormancy in the trees.

The behavior of tree ring growth in relation to precipitation month by month (Figure 2) shows that the tree growth was directly related to precipitation in the months of the activity (September to March), which showed significant correlations.

In Figures 2 and 3, it is possible to detect that influence of climatic variables on plant growth for the year T occurred almost at the same period of T-1. For Höll (1985) cited in Andreacci et al. (2014), the positive correlation between chronology and precipitation in T-1 may indicate that the water supply may be used by the plant in the next growing season. Small variations in scale and reversal of the direction of the correlation were not linked to the months whose correlations were significant, such as June and November for precipitation and June and January for temperature.

For temperature, the correlations in T and T-1 were negative in winter, especially in August. Negative correlations for the entire period from July to October may be due to low_growth of plants during the winter months. This result corroborates the proposal of Stokes and Smiley (1996) and Botosso and Mattos (2002) who suggest that the growing season of plants occurs in spring / summer (earlywood) and the dormant period occurs in autumn / winter (latewood).

The behavior of the reconstruction curve fits well the rainiest and less rainy periods from the original precipitation series. The precipitation profile before 1961 is indicated by the reconstructed series and shows that there was more precipitation for the months from September to March between 1907-1938 and 1939-1960, whereas the period of 1929-1937 recorded less precipitation.

It is important to keep in mind that tree growth is influenced by the climatological variables as well as many other elements that were not studied in this work (KANIESKI et al., 2012). In some trees and/or in some periods of the year, the greatest influence may have been those other factors.

\section{CONCLUSION}

This study showed that the plant growth represents the local climate characterized by rainier spring / summer, which provided sufficient water for the plant during the growing season. Winters are dry and cold and tend to induce dormancy, which was clearly shown by significant and negative correlations between chronology and winter temperatures in $\mathrm{T}$ and $\mathrm{T}-1$.

Precipitation did not show a clear profile of influence on plant growth on a monthly or yearly scale, but did in all set of months during activity of plants in $\mathrm{T}$ and $\mathrm{T}-1$.

For reconstruction it is important to note: (1) the precipitation series used in this study is short; (2) the reconstruction is only for growth months of the plant in which the best correlation between month by month chronology and tree-ring series were obtained; (3) the reconstruction presented the precipitation profile over time.

These results, if based on a larger sample, could find more definite results (VINCENT et al., 2007). Nevertheless, the results indicate some relationship between $A$. angustifolia growth and local climate.

\section{REFERENCES}

ANDREACCI, F.; BOTOSSO, P.C.; GALVÃO, F. Sinais climáticos em anéis de crescimento de Cedrela fissilis em diferentes tipologias de florestas ombrófilas do Sul do Brasil. Floresta, v.44, n.2, p.323-332, 2014.

BORGAONKAR, H.P.; SIKDER, A. B.; RAM S.; PANT, G.B. El Niño and related monsoon drought signals in 523-years-long ring width records of Teak (Tectona grandis L.F.) trees from south India. Palaeogeography, Palaeoclimatology, Palaeoecology, v.285, n.1, p.74-84, 2010.

BOTOSSO, C.P.; MATTOS, P.P. Conhecer a idade das árvores: importância e aplicação. Colombo: Embrapa Florestas, 2002. 25p.

CARVALHO, S.M.; STIPP, N.A.F. Contribuição ao estudo do balanço hídrico no estado do Paraná: 
Uma proposta de classificação qualitativa. Geografia, v. 13, n.1, jan/jun. 2004.

COELHO, J.V. Dendrocronologia: Método matemático para determinação da idade das árvores. 2011. 100f. Tese (Doutorado em Física Ambiental) - Universidade Federal do Mato Grosso, Cuiabá, 2011.

CUSATIS, C.A.; TRAZZI, P. A.; DOBNER JUNIOR, M.; HIGA, A. R. Dendroecologia de Cedrela fissilis na Floresta Ombrófila Mista. Pesquisa Florestal Brasileira, v. 33, n.75, p.287-297, 2013.

ENQUIST, B.J.; LEFFLER, A.J. Long-term tree ring chronologies from sympatric tropical dry-forest trees: individualistic responses to climate variation. Journal of Tropical Ecology, v.17, n. 1, p.41-60, 2001.

FICHTLER, E.; TROUET, V.; BEECKMAN, H.; COPPIN, P.; WORBES, M. Climatic signals in tree rings of Burkea Africana and Pterocarpus angolensis from semiarid forest in Namibia. Trees, v.18, p.422-451, 2004.

FLOWER, A.; SMITH, D.J. A dendroclimatic reconstruction of June-July mean temperature in the northern Canadian Rocky Mountains.

Dendrochronologia, v.29, n.1, p.55-63, 2010.

HIGUCHI, N.; CHAMBERS, J. Q.; SILVA, R. P.; MIRANDA, E. V.; SANTOS, J.; IIDA, S.; PINTO, A. C. M.; ROCHA, R. M.; SOUZA, C. A. S. Uso de bandas metálicas e dendrômetros automáticos para definição do padrão de crescimento individual das principais espécies arbóreas da floresta primária da região de Manaus, Amazonas, Brasil. In: HIGUCHI, N.; SANTOS, J.; SAMPAIO, P. T. B.; MARENCO, R. A.; FERRAZ, J.; SALES, P. C.; SAITO, M.; MATSUMOTO, S. (Org.). Projeto Jacaranda: fase II: pesquisas florestais na Amazônia Central. Manaus: INPA, Coordenação de Pesquisas em Silvicultura Tropical, 2003.p. 55-68.

HÖLL, W. Seasonal fluctuation of reserve meterials in the trunk Wood os spruce (Picea abies) (L.) Karst). Journal Plant

Physiology, v.117, p.335-362, 1985.

KANIESKI, M.R.; SANTOS, L. T.; NETO, G. J.; SOUZA, T.; GALVÃO, F.; RODERJAN, C. V.
Influência da precipitação e da temperatura no incremento diamétrico de espécies florestais aluviais em Araucária - PR. Floresta e Ambiente, v.19, n.1, p.17-25, 2012.

LISI, C.S.; PESSENDA, L.C.R.; TOMAZELLO, M. ${ }^{14} \mathrm{C}$ Bomb effect in tree rings of tropical and subtropical species of Brazil. Tree-Ring Research, v.57, n.2, p.191-196, 2001.

LORENSI, C. Estudo de eventos de El Niño e La Niña em anéis de crescimento de árvores para a região sul do Brasil. 2012. 116f. Dissertação (Mestrado em Meteorologia) - Universidade Federal de Santa Maria, Santa Maria, 2012.

MOREIRA, T.C.L. Interação da vegetação arbórea e poluição atmosférica na cidade de São Paulo. 2010.81f. Dissertação (Mestrado em Recursos Florestais) - Escola Superior de Agricultura "Luiz de Queiroz", Piracicaba, 2010.

MURPHY, J.O. Australian tree ring chronologies a proxy data for solar variability. Proceedings ASA, v.8, n.3, p.292-297, 1990.

OLIVEIRA, J.M. Anéis de crescimento de Araucaria angustifolia (Bertol) O. Kuntze: bases de dendroecologia em ecossistemas subtropicais montanos no Brasil. 2007. 139f. Tese (Doutorado em Ecologia) - Universidade Federal do Rio Grande do Sul, Porto Alegre, 2007.

OLIVEIRA, J.M.; ROIG, F.A.; PILLAR, V.D. Climatic signals in tree-rings of Araucaria angustifolia in the southern Brazilian highlands. Austral Ecology, v.35, p.134-147, 2010.

PRESTES, A.; RIGOZO, N. R.; NORDEMANN, D. J. R.; WRASSE, C. M; SOUZA ECHER, M.P.; ECHER, E.; da ROSA, M. B.; RAMPELOTTO, P. H. Sun-earth relationship inferred by tree growth rings in conifers from Severiano de Almeida, Southern Brazil. Journal of Atmospheric and Solar-Terrestrial Physics, v.73, p.1587-1593, 2011.

RIGOZO, N.R. Registros da atividade solar e de outros fenômenos geofísicos em anéis de crescimento de árvore.

Revista Árvore, Viçosa-MG, v.40, n.2, p.347-354, 2016 
1999. 133f. Tese (Doutorado em Geofísica Espacial) - Instituto Nacional de Pesquisas Espaciais, São José dos Campos, 1999.

RIGOZO, N. R.; PRESTES, A.; NORDEMANN, D. J.R.; da SILVA, H. E.; SOUZA ECHER, M. P.; E. ECHER. Solar maximum epoch imprints in treerings width from Passo Fundo, Brazil (17412004). Journal of Atmospheric an SolarTerrestrial Physics, v.70, p.1026-1033, 2008.

SANTAROSA, E.; OLIVEIRA, J. M.; ROIG, F. A.; PILLAR, V. D. Crescimento Sazonal em Araucaria angustifolia: Evidências Anatômicas. Revista Brasileira de Biociências, v.5, supl. 1, p.618-620, 2007.

SAVVA, Y.; SCHUWEINGRUBER, F.; MILYUTIN, L.; VAGANOV, E. Genetic and environment signals in tree rings from different provenances of Pinus sylvestris L. planted in the southern taiga, central Siberia. Trees, v.16, p.313-324, 2002.

\section{SCHWEINGRUBER, F.H. Tree rings and} environment: dendroecology. Berne: Haupt Press, 1996. 609p.

SILVA, A.; PRESTES, A. Estudo dendroclimático da Região de São Francisco de Paula - RS. In: ENCONTRO LATINO AMERICANO DE POS GRADUAÇÃO, 10., 2010, São José dos Campos. Anais... São José dos Campos: 2010. 5p. CD-ROM.
STOFFEL, M.; PERRET, S. Reconstructing past rockfall activity with tree rings: Some methodological considerations.

Dendrochronologia, v.24, p.1-15, 2006.

STOKES, M.A.; SMiley, T.L. An introduction to tree-ring dating. Tucson: University of Arizona Press, 1996. 73p.

TROVATI, L.R.; FERRAZ, E.S.B. Influência da precipitação e da temperatura na densidade dos anéis de crescimento de Pinus oocarpa. IPEF, v.26, p.31-36, 1984.

VINCENT, L.; PIERRE, G.; MICHEL, S.; ROBERT, N.; MASSON-DELMOTTE, V. Tree-rings and the climate of New Caledônia (SW Pacific) Preliminary results from Araucariaceae. Paleogeography, Paleoclimatology, Paleoecology, v.257, p.477-489, 2007.

ZANON, M.L.B.; FINGER, C.A.G. Relação de variáveis meteorológicas com o crescimento das árvores de Araucaria angustifolia (Bertol.) Kuntze em povoamento implantados.

Ciência Florestal, v.20, n.3, p.467-476, 2010.

ZANZI, A.; PELFINI, M.; MUTTONI, G.; SANTILLI, M.; LEONELLI, G. Spectral analysis on mountain pine tree-ring chronologies.

Dendrochronologia, v.24, p.145-154, 2007. 